\title{
PRODUCER GAS FOR MOTOR VEHICLES
}

$\mathrm{T}$ HE recently published "Report of the Committee on the Emergency Conversion of Motor Vehicles to Producer Gas"' (London : H.M. Stationery Office, 1940. 9d. net) conveys conclusions only. The Committee, set up by the Mines Department in May 1937, carried out extensive experimental work, including bench tests and road tests under normal operation and under scientifically controlled conditions, from which it can be inferred that a considerable body of quantitative information was derived. The data, however, have not been published; presumably it was not desirable to give details of the work at the present time.

Road trials with commercial producers showed that, subject to certain inherent limitations, producer gas is a satisfactory fuel for transport vehicles. The Committee was impressed by the difficulties encountered and the special conditions attending such an emergency as was envisaged, and therefore undertook the design of a simple producer which would be suitable for the conversion of existing vehicles, capable of rapid production at low cost and required only such metals, plant and labour as were likely to be available in war-time.

Although on the Continent considerable numbers of vehicles have been operated by producer gas, the small amount of progress made in Great Britain is put down to increased capital maintenance and servicing costs, reduction in power output with the consequent upsetting of operating schedules, reduced pay load and the difficulty of obtaining suitable fuel. The artificial disadvantages due to such vehicles being placed in higher tax and lower speed-limit categories are probably more potent considerations. It is stated that the vehicles operated by the Com. mittee have covered a distance of more than 170,000 miles, but no information is adduced regarding these trials. Nor are any figures given of the results obtained in Continental practice, although several members of the Committee had already studied the use of producer gas vehicles on the Continent, and close watch was kept on developments taking place abroad.

The design, which the Committee states is not suggested as necessarily representing finality, appears to be suitable for vehicles up to 6 tons gross weight of 3-4 litres engine capacity. Grave difficulties in operation were found to follow relatively minor constructional defects, and failure to adhere strictly to the dimensions laid down has frequently led to trouble. The design as outlined appears to have the merit of simplicity from the point of view of manufacture and lends itself to mass production. It is suitable for use with low-volatile anthracite and certain low-temperature cokes, and may be mounted on the vehicle itself or on a trailer as thought best in each individual case. We are informed that full details regarding the plant and its working can be obtained from the Director, Fuel Research Station, London, S.E.10.

There are among the conclusions reached by the Committee several valuable items of information such as the availability of different classes of suitable fuel, effective methods of gas filtration and the classes of service for which gas producer vehicles can be most economically used.

\section{EXPLOSIVE ACTIVITIES OF A JAPANESE VOLCANO}

\begin{abstract}
THE volcano Kusatu-Sirane suddenly became active with a remarkable explosion on November 27,1937 , and from that time until October 1938 it was studied in great detail by T. Minakami (Bull. Earthquake Res. Inst., Tokyo Imp. Univ., 17, Part 3, September 1939, pp. 590-623). The voleano was very active during December 1937, and January and February 1938. It was more calm from April.until August 1938, but became active again from the latter part of September. A rather violent explosion occurred on October 5, 1938, and after that date large quantities of gas were ejected, while ash was scattered near the $Y$ crater. At the same time, volcanic pulsations and volcanic micro-earthquakes occurred and these were still continuing in February 1939.

So far as situation on the earth's surface is concerned, the active fissure differed from the fissure of previous activity of October 1932. The hypocentres of the micro-earthquakes were found to be at a depth of $1.7 \mathrm{~km}$. According to geothermic measurements, the region of high temperature was restricted to the narrow zone along the active fissure. From observa-
\end{abstract}

tions of the water-level of the hot spring pond in the crater, it was concluded that the quantity of water that filtered through the fissure at the bottom of the pond amounted approximately to 750 tons a day. The gas ejected from the crater was mostly aqueous vapour, though on several days during May and October 1938 large quantities of evaporated sulphur were emitted with the steam. Boring showed that the floor of the $Y$ crater consisted of alternate layers of precipitated sulphur, voleanic detritus and ash.

The presence of the sulphur gave the estimate of $444^{\circ} \mathrm{C}$. for the temperature of the vapour, though often it was below this temperature. The quantity of seeping water would affect this, as would the supply of heat from the subterranean origin. Judging from the distribution of volcanic detritus, the pressure of gas at the time of the principal explosions under discussion was almost 150 atmospheres, which is slightly less than that of the explosion of October 1932 as calculated by T. Matuzawa.

H. Tsuya suggests that these explosions were phenomena near the earth's surface resembling those of a geyser. 